\title{
Valuing ecotourism and conservation benefits in Marine Parks : the case of Redang Island, Malaysia.
}

\begin{abstract}
The purpose of this study is to estimate the visitors preferences of ecotourism attributes in Redang Island Marine Park. This study employs the Choice Experiments (CE), the Conditional Logit (CL) to investigate the visitors' preferences of the ecotourism attributes. The personal interview has been made with a total of 298 representative respondents. The respondents has been asked to select the best among the alternatives of ecotourism attributes. The ecotourism attributes which have been investigated are ecological management, recreational activity congestion, provision of employment opportunity to local people and conservation charge. Results of the study found that the visitors preferred the highest changed in ecological management attribute levels compared to recreational activity congestion and provision to local employment attributes levels. Results of this study are very important in assists policy maker in management and development plan for ecotourism in marine parks.
\end{abstract}

Keyword: Ecotourism; Economic valuation, Choice experiments; Conditional logit models; Marine parks; Sustainable development. 